\title{
Satanisme gesien vanuit 'n pastorale perspektief
}

\author{
J M Bevolo-Manders \& T F J Dreyer \\ Departement Praktiese Teologie (Afd A) \\ Universiteit van Pretoria
}

\begin{abstract}
Satanism seen from the perspective of pastoral counselling Based on observations of Satanism and exorcism, the article suggests that pastors are confronted with two world views which are in conflict with one another: the mythological world view of the New Testament and the modern world view. The article explores the consequences of these conflicting worla views for ministers counselling individuals cuught up in the practices of satanism.
\end{abstract}

\section{INLEIDING}

Hierdie artikel fokus op sekerlik een van die mees omstrede onderwerpe van ons tyd. Satanisme is 'n realiteit, 'n 'kanker'-godsdiens is dit al genoem. Satanisme is 'n skrikwekkende realiteit vir baie. Op grond van waamemings op die terrein van Satanisme en eksorsisme, is die vermoede dat ons hier gekonfronteer word met twee wêreldbeelde wat met mekaar bots. Enersyds is daar ' $n$ mitologiese wêreldbeeld van die Nuwe Testanent en andersyds 'n moderne wêreldbeeld. Indien hierdie hipotese bevestig kan word, sal dit noodwendige konsekwensies vir die pastoraat inhou. Ons kan hieruit aflei dat mense, ten spyte daarvan dat hulle deel uitmaak van die moderne wêreld, steeds in 'n mitologiese verwysingsraamwerk vasgevang is.

Volgens Bultmann (kyk Pelser 1987:168) is dit onmoontlik om vandag van mense te verwag om hierdie mitologiese wêreldbeeld te aanvaar, omdat ' $n$ mens eenvoudig nie deur ' $n$ besluit ' $n$ wêreldbeeld kan oorneem nie. 'n Wêreldbeeld is reeds 'n gegewene in die historiese situasie waarin mense hulle bevind. Net so is met die moderne denke die kritiek op die Nuwe-Testamentiese wêreldbeeld 'n gegewene. Geen mens kan met erns hierdie wêreldbeeld onderskryf nie. Die vraag is of ons, in die lig van die moderne wêreldbeeld, van hedendaagse mense kan verwag dat hulle 'n sacrificium intellectus moet pleeg deur iets vir waar te moet aanvaar bloot omdat dit in die Bybel staan (Pelser 1987:168)?

* Hierdie artikel is 'n verwerking van die resultate van die BD-skcripsie, ingedien en anvaar as deel van die vereistes vir die BD-graad (1996), Departement Praktiese Teologie (Afd A), Universiteit van Pretoria, onder leiding van prof dr T F J Dreyer. 
betekenis gekry van die maniere en middele waardeur mense deur hulle religie met die bo-natuurlike wêreld in aanraking kom of kommunikeer (Smit 1992:3). Hierdie kommunikasie met die bonatuurlike wêreld is bereken om die hele mens te raak:

* die gevoelslewe deur die mistiek;

* die verstand en wil deur die mantiek;

* die beheersing van die mens se leefwêreld deur die magie;

* en die behoefte aan die verering van geestelike wesens (Smit 1992:3).

\section{2 'n Werksdefinisie}

Okkultisme is dus die maniere wat mense buite en sonder die Bybel, persoonlik en in groepsverband in hulle godsdiens aanwend om met die bonatuurlike te kommunikeer, sodat hulle hulle religieuse behoeftes kan bevredig en hulle leefwêreld kan beheer (Smit 1992:3).

\subsection{Satanisme}

Satanisme is een van die vorme van okkultisme. Satanisme word gedefinieer as 'n charismaties-religietse kultus, wat gekarakteriseer word deur die godslasterlike omkering van Christelike norme en die Christelike ideologie en die aanroeping van Satan as voorwerp van verering en diens (Ivey 1993:180). Satanisme het die volgende met ander charismatiese groepe in gemeen:

* 'n gekodifiseerde bonatuurlike geloofsisteem;

* 'n hoë vlak van sosiale kohesie;

* die gedragnorm van die groep beinvloed die lede grootliks;

* en die toekenning van charismatiese of goddelike krag aan die groep of sy leierskap (Ivey 1993:180).

Satanisme word egter van ander kultusse onderskei, angesien die identiteit en karakter daarvan berus op die negasie en omkering van 'n ander religieuse tradisie naamlik die Christendom (Ivey 1993:180).

\subsection{Demonisme of demoniese besetenheid}

'n Tentatiewe werksdefinisie van demoniese besetenheid: Dit is 'n (psigiese) toestand 
Met hierdie studie sal gepoog word om Satanisme as fenomeen in die modeme samelewing psigologies te analiseer en te beskryf en om die verskynsel van die bose teologies-hermeneuties te omskryf. Aangesien die ondersoek afgestem is op die realiteit van satanisme en die moontlike kerklikpastorale bediening aan hulle wat hierin vasgevang is, moet daar dus nie verwag word dat aan alle aspekte van demonologie in die Nuwe Testament aandag gegee sal word nie. Verder sal daar in die loop van die studie, vanuit 'n pastorale perspektief, aandag gegee word aan die lidmate wat in die praktyk van satanisme vasgevang is en hoe hulle begelei word tot 'bevryding', met inagneming van die moderne wêreldbeskouing of lewensklimaat. Dit gaan aan die pastorale gesprek die eis stel om in 'n 'taal' te praat wat lidmate ontvanklik sal stem en wat sal coreenstem met hulle verwysingsraamwerk ten einde 'sukses' in die pastorale gesprek te waarborg.

Die okkulte is so oud soos die mensheid en die religie self. Deur die eeue is dit in die skaduwee van die Christelike kerke van die Eerste en Tweede Wêreld beoefen in die vorm van heksery, bloedpakte, magiese ordes, magie, mistisisme, spiritisme en mantiek (Smit 1992:1-2). Die aktualiteit van die onderwerp kom juis daarin na vore dat daar in die laaste dekades van die twintigste eeu 'n oplewing in belangstelling in die okkulte is. Ons hoor van die 'Kerk van Satan' van Anton Le Vey in die VSA; van die sinistêre geheime byeenkomste oral in Suid-Afrika waar anti-Christelike simbole en anti-kerklike rituele en satanistiese praktyke gepleeg word. Ons hoor van die swart mis en bloedpakte en seksorgies en dwelms en graf-en lykskendings en gruweldade met diere en kinderoffers! Ons kan nie meer ons oë sluit vir die nuwe religieuse subkultuur wat in ons midde opgestaan het nie - die sub-kultuur van die okkult betrokkene. Van-hierdie sub-kultuur moet ons 'n studie maak sodat ons aan die mense wat daarby betrokke is die evangelie van Jesus Christus, genuanseerd en toegespits op hulle behoefte kan bedien (Jonker 1993; Janson 1993; Smit 1992).

\section{BEGRIPSVERHELDERING}

Om die spraakverwarring wat daar rondom satanisme, okkultisme en die bonatuurlike en paranormale verskynsels ontstaan het, hok te slaan, is dit nodig om met die omlyning van 'n paar begrippe te begin.

\subsection{Okkultisme}

Die omvattende religieuse begrip, vir die mens se betrokkenheid by die bo-natuurlike, is die okkulte. Die woord 'okkult' kom uit Latyn en beteken 'verborge'. Dit dui op dit wat vir die sintuiglike waarneming verborge is, die bonatuurlike, wat dus op 'n ander manier as deur die sintuie geken moet word. So het die okkulte die verdere 
* wat manifesteer in reaksie op 'n direkte konfrontasie met die evangelie van Jesus Christus; die reaksie op die evangelie is een van weerstand en agressie;

* wat nie in verband gebring kan word met 'n sielkundige of medies identifiseerbare siektetoestand nie;

* wat 'n persoonlikheidsverwisseling meebring;

* wat tekens van okkulte vermoëns vertoon;

* wat saamhang met en voortvloei uit die betrokkenheid by en deelname aan okkulte praktyke (Smit 1992:4).

\subsection{Ontmitologisering - binne 'n moderne wêreld}

Pelser (1989:815-816) vat Bultmann se ontmitologiseringsprogram soos volg saam:

Die mitiese denkwyse wat in die Nuwe Testament tot uitdrukking kom, kan volgens Bultmann eenvoudig nie meer gehandhaaf word nie. Bultmann begin sy 1941-voordrag met die stelling dat die wêreldbeeld van die Nuwe Testament mities is. Die wêreld word gesien as bestaande uit drie afdelings, te wete die hemel, die aarde en die onderwêreld. Die hemel is die woonplek van God en die hemelse gestaltes; die engele; die onderwêreld is die hel, die plek van ellende waar die duiwel sy woonplek het. Maar ook die aarde is nie 'n plek van die natuurlik-alledaagse gebeurtenisse nie. Dit is die toneel van die bedrywighede van bonatuurlike magte: God en sy engele, die Satan en sy demone. Hierdie magte gryp in in die natuurlike verloop van sake asook in die denke, wil en handelinge van mense. Die mens het nie mag oor homself nie, demone kan van hom besit neem en die Satan kan bose gedagtes by hom wek. Maar ook God kan die mens se denke en wil rig, kan hom hemeise gesigte laat sien, hom sy bevelende of vertroostende woord laat hoor en aan hom die bonatuurlike krag van sy Gees skenk. Die geskiedenis loop ook nie sy bestendige, wetmatige gang nie, maar verkry sy beweging en rigting van die bonatuurlike magte. Hierdie aion staan onder die mag van die Satan, die sonde en die dood en is vinnig op pad na sy einde toe, 'n nabye einde wat hom as 'n kosmiese katestrofe sal voltrek. 
Om hierdie mitiese wêreldbeeld in die moderne tyd te bly handhaaf en van die moderne mens te verwag om dit te aanvaar, is volgens Bultmann beide sinloos en onmoontlik. Dit is sinloos omdat hierdie wêreldbeeld as sodanig nie spesifiek Christelik is nie, maar eenvoudig die wêreldbeeld is van 'n vergange tyd wat nog nie deur wetenskaplike denke gevorm was nie.

Die mens wat die mitiese denke ontgroei het, sien homself as 'n eenheid en skryf sy gevoelens, denke en wil aan homself toe en nie meer aan die ingrype van demoniese of goddelike magte toe nie. En al is dit so dat sy geestelike lewe nie los van sy liggaamlikheid staan nie, weet hy dat hy sy selfstandigheid as persoon telkens weer moet laat realiseer. Juis om hierdie rede weet hy van sy verantwoordelikheid vir homself en vir sy vryheid. Hy kan homself in sy verhouding tot God ook slegs as 'n persoon sien wat in sy bestaan as persoon deur God aangespreek word.

Die volgende redes word aangevoer vir die ontmitologisering van die Nuwe-Testamentiese mitologie: (a) die wêreldbeeld van die moderne wetenskaplike georiënteerde mens het so verander dat hy hom nie meer kan vereenselwig met die wêreldbeeld van die Nuwe Testament nie; (b) die intensie van die mite self is nie om 'n objektiewe wêreldbeeld aan ons op te dring nie, maar om tot uitdrukking te bring hoe die mens homself in sy wêreld verstaan, en dat dit daarom nie kosmologies nie maar antropologies, beter nog, eksistensieel geinterpreteer wil word; (c) deur middel van ontmitologisering moet die waarheid van die kerugma as kerugma by die nie-mitologies denkende mens tuisgebring word; (d) die Nuwe Testament stel self die vereiste vir ontmitologisering vanweë die feit dat daarin voorstellings voorkom wat mekaar weerspreek en vanweë die feit dat ontmitologisering reeds hier en daar in die Nuwe Testament self voorgekom het.

\section{3. 'n TEOLOGIES-HERMENEUTIESE OMSKRYWING VAN DIE BOSE IN DIE NUWE TESTAMENT}

\subsection{Satanisme in die Nuwe Testament}

Soos reeds vermeld, word satanisme gedefinieer as 'n religieuse kultus waarin mense Satan aktief aanbid en dien. Die vorm waarin ons satanisme gedefinieer het, kom nie in die Nuwe Testament voor nie. Spore hiervan tref ons aan waar melding gemaak word van persone wat toorkunste beoefen (vgl Hand 8:9-24; 16:16; 19:19). In die 
sinoptiese evangelies is daar egter volop sprake van demoniese besetenheid. 'n Mens sou agter hierdie verskynsel ten minste okkultiese betrokkenheid kon veronderstel. Okkultiese praktyke is immers so oud soos die berge (vgl Saul en die dodebesweerster van En-Dor; 1 Sam 28). Dit word egter nie direk vermeld dat mense besete was as gevolg van sulke praktyke nie. Die klem val eerder op die bevryding van hierdie ongelukkiges (Van Zyl 1992:9).

\section{2 'n Beskrywing van Satan en demone in die Nuwe Testament}

Dit is nie Nuwe-Testamentici se taak om bloot 'n beskrywing van die Satan en demoniese bedrywighede wat in die Nuwe Testament voorkom, te gee nie. Dit is nie hulle taak om almal onder die indruk te bring van die verskriklike werklikheid van 'n persoonlike duiwel en Satan se ryk van demone nie. Hierdie gegewens vanuit die Nuwe Testament kan cok nie links en regs betrek word om steun te gee aan die moderne verskynsel en standpunt van satanisme nie (Van Zyl 1992:9).

\subsubsection{Joodse agtergrond}

Dit is noodsaaklik dat daar deeglik kennis geneem sal word van die Joodse agtergrond, om die gegewens in die Nuwe Testament oor die duiwel en demone te verstaan. Die Joodse (by)geloof oor, weergawe van en praktyke rondom die okkulte, vorm die basis van die voorkoms daarvan in die Nuwe Testament. Die skrywers van die Nuwe Testament (met moontlike uitsonderings) was almal Jode wat Jesus (wat ook 'n Jood was) vanuit hierdie agtergrond as die Messias gevolg het. Hulle belewing was dus gedrenk in en gekleur deur 'n Joodse milieu. En dit is hierdie simboliese universum wat neerslag gevind het in die geskrifte van die Nuwe Testament (Van Zyl 1992:10).

In vergelyking met die Nuwe Testament, vertoon die Ou Testament min gegewens cor die duiwel. Die monistiese * 3reldbeeld, waarvolgens God grootliks as die enigste corsaak van alle gebeure beskou is, is deels hiervoor verantwoordelik. Die verhoogde voorkoms van die duiwel en demone in die Nuwe Testament kan toegeskryf word aan die dualistiese wêreldbeeld. Gelowiges kon dit nie aanvaar dat God vir lyding verantwoordelik kon wees nie. In die lig hiervan het die opvatting ontstaan dat daar 'n teenmag moes wees. Die klassieke voorbeeld van 2 Samuel 24:1 en 1 Kronieke 21:1 illustreer dit treffend (Van Aarde 1987:23-24).

Waar hierdie dualistiese wêreldbeeld en die Satansfiguur vandaan kom, is egter nie aan ons bekend nie. Die diaspora-Jode se blootstelling aan die invloed van die Zoroastriese godsdiens van die Perse, waarin enersyds 'n sterk dualistiese tendens asook transendente kosmologiese spekulasies voorgekom het en andersyds die ontwikkeling in dié van Israel self, het moontlik hiertoe bygedra. Geloof in allerlei demone 
en geeste - goed en sleg - was glad nie vreemd nie. In detail is beskryf hoe hierdie geestes- en demonewereld saamgestel is; daar is verwys na die aard, hiërargie en funksies van die demone en geeste en daar is beskryf hoedat 'n persoon daarteen beveilig kon word (Van Zyl 1992:11).

\subsubsection{Nuwe-Testamentiese gegewens}

Die gegewens wat ons in die Nuwe Testament aantref aangaande die bose, kan in drie kategoriee verdeel word: Daar is verskillende benaminge vir hierdie figuur, onder andere: die duiwel (Matt 4:1); Satan (Matt 4:10); Beëlsebul (Matt 10:25); Beliar (2 Kor 6:15). Enkele kenmerke en funksies van die duiwel is: die personifikasie van die Bose; die veroorsaker van siektes en besetenheid (Luk 13:11,16); die verleier van mense tot sonde en vernietiging (Joh 13:2) ensovoorts. Met die eindoordeel kom Satan se ryk egter effektiewelik tot 'n einde (Op 20:9-10) (Van Aarde 1987:28).

Dil is nodig dat ons sal onderskei tussen die begrippe 'duiwel' en 'demone'. Eersgenoemde dui op die 'hoofduiwel', die aanvoerder van die ryk van die Bose, en word in Grieks met diabolos weergegee, terwyl 'demone' (Grieks daimonia) slaan op die volgelinge en onderdane van die Duiwel. Demone word veral in die sinoptiese evangelies aangetref, waar hulle besondere groot mag op mense uitoefen en hulle baie skade berokken. Sekere uitsonderlike siektetoestande loop selfs hand aan hand met demoniese besetenheid (vgl Matt 17:14-21). Hierdie nie-menslike, geestelike wesens tree as vyande en teenstanders van Jesus op (Van Zyl 1992:13; Van Aarde 1987:26).

\section{* Onpersoonlike magte}

Die bo-natuurlike, onpersoonlike magte waaraan die mens uitgelewer is, word beskryf deur 'n verdere groep benamings. Meesal word hierdie terme gebruik in kontekste waar dit oor die Bose handel, andersins funksioneer dit neutraal. Byvoorbeeld: magte, trone, engele (Ef 1:21, 6:12; Kol 1:16).

\subsection{Sistematisering en interpretasie van Nuwe-Testamentiese gegewens oor die Bose}

Dit sou verkeerd wees om aan demone selfstandige, outonome status toe te ken. Die duiwel en dié se ryk dien bloot as agtergrondskildering vir die werk van Jesus en kom slegs aan die lig as die skadukant van die evangelie. Daarom kan ons slegs vanuit die soteriologie en die Christologie sinnig daaroor praat (Van Aarde 1987:33). In die Nuwe Testament dui demonologie op 'n dualisme, op die konflik tussen goed en 
kwaad. Hierdie konflik is so oud soos die mensheid self. Demonologie in die Nuwe Testament het prinsipieel 'n etiologiese motief gehad. Hierdie motief was om die oorsprong, sowel as die funksionering van die bose te verklaar (Van Aarde 1987:34).

Indien ons die voorkoms van die duiwel in die Nuwe Testament sou vergelyk met die in buite-Bybelse geskrifte sal daar verwonderd gestaan word oor die merkwaardige terughoudendheid en soberheid waarop daar in die Nuwe Testament oor die duiwel geskryf is. Daar word nie in die Nuwe Testament gespekuleer oor die herkoms, werking en hiërargie van die duiwel nie. Slegs die essensiële word meegedeel (Van Zyl 1992: 15-16). Dit is nie die Christengelowige of -teoloog se taak om alles omtrent die duiwel te wete te kom nie. 'n Christen se lewe moet immers Christusgesentreerd wees en nie duiwelgesentreerd nie. Miskien moet Karl Barth se woorde ter harte geneem word. Hy het gesê dat dit voldoende is om 'n kort, skerp kyk in die donker ryk van die duiwel te gee en dit daarby te laat (Van Zyl 1992:15-16).

Russell (1977:205) vergelyk die bose metafories met die gate in 'n Switserse kaas. Die gate is daar, maar dit is slegs daar as nie-kaas en bestaan nie sonder die kaas nie. Net soos wat 'n mens nie die kaas kan eet en die gate iewers wegpak nie, net so kan 'n mens nie die goeie opsyskuif en die bose in 'n ander kategorie plaas nie.

\subsection{Duiwel as oorwonne vyand}

In die Nuwe Testament word die duiwel ontbloot vir dit wat dit werklik is, naamlik: 'n oorwonne vyand. Ons sien dit in die wyse waarop Jesus die versoekings van Satan die hoof bied; ons sien dit wanneer Jesus demone uitdryf en laastens waar Satan finaal verslaan word aan die kruis. Jesus sê self in Lukas 10:18 dat Hy Satan soos 'n weerligstraal uit die hemel sien val het (Van der Watt 1993:31, 35). In die Nuwe Testament tref ons talle weergawes aan van demoonuitdrywings (eksorsismes). Eksorsisme is egter nie 'n praktyk waarvan daar slegs in die Nuwe Testament melding gemaak word nie. Eksorsisme was 'n wyd verbreide praktyk in die Nabye Ooste. Die weergawes in die Nuwe Testament (i v m buite-Bybelse geskrifte) is weereens tekenend van cenvoud en soberheid. Ons vind in die Nuwe Testament geen beskywing van uitvoerige prosedures, formules en rituele wat so tipies was van die ander geskrifte se beskrywings nie. Jesus het slegs 'n magswoord gespreek en die demoon het die besetene verlaat (Van Zyl 1992:17-18).

\subsection{Siek of besete?}

In 'n referaat wat gelewer is deur Van Zyl (1992:18) waar hy 'n Nuwe-Testamentiese perspektief bied op die demonologie, maak hy die baie belangrike stelling dat wtreld- 
beeld en demonologie nie van mekaar geskei kan word nie. Hiermee lê hy die volgende belangrike vrae op die tafel: wat is waarheid en wat is verdigsel in demonologie? In hoe 'n mate moet ons alles wat in die Nuwe Testament as die werking van die demone aangemerk word, presies nog so vir vandag aanvaar? Waaroor wil die Bybel ons gesagvol inlig?

Ons veranderde wêreldbeeld, ons meerdere kennis van siekteverskynsels en ons insig in die wêreld van die Nuwe Testament lei daartoe dat daar sekere verskynsels in die Nuwe Testament is wat ons anders sal interpreteer as demoniese werking. Ons moet besef dat demonologie in 'n groot mate die destydse 'natuurwetenskaplike' verklaring van ten minste sommige siekteverskynsels was. Veral die voorkoms van abnormale gedrag by mens en dier, wat nie as 'normale' siektetoestande geëien kon word nie, is dikwels aan demoniese werking toegeskryf. Sommige verskynsels wat in die Nuwe Testament as demoonbesetenheid aangedien word, sou vandag moontlik as nie-demoniese psigosomatiese siektetoestande gediagnoseer kon word. Hiermee word natuurlik nie die boodskap vervat in die optekening van hierdie gebeure, weggeredeneer nie. Die bedoeling is duidelik: Jesus verbreek die mag van die bose (Van Zyl 1992:19).

In die moeilike gebiede dui die Nuwe Testament self vir ons die probleemareas en koers aan. Hierbo is gemeld dat demoonbesetenheid in die Nuwe Testament bykans altyd met siektetoestande verband hou. En gewoonlik is dit die gevalle wat die grense van normale siektebeelde corskry (bv Matt 17:14-18). Daar is egter ook gevalle waar gewone, alledaagse siektes met demone in verband gebring word, byvoorbeeld blindheid, stomheid, koors en kromtrekking (vgk Matt 9:32; Luk 4:39 - die 'bestrawwing' van die koors in laasgenoemde dui op 'n demoniese oorsaak. Natuurlik is daar hedendaagse voorbeelde van die gebreke wat ook 'n sielkundige basis het (bv histeriese blindheid), wat in bepaalde gevalle onder die noemer van besetenheid gebring sou kon word. Maar die blote feit dat sulke gewone siektes in die Nuwe Testament (soms) as demonies van oorsprong aangedui word, illustreer die kader waarbinne mense destyds na siekte gekyk het. Dit was as 't ware 'in die lug', tweede natuur, om by die geringste aanleiding 'n demoon verantwoordelik te hou (Van Zyl 1992:19).

Hoewel daar dus in die Nuwe Testament 'n mate van onderskeid tussen gewone siektes en siektes as gevolg van demoniese werking gehandhaaf word, is dit geen waterdigte skeiding nie. In die algemeen kan 'n mens sê dat demonologie as verklaring van anomaliese siekteverskynsels - dit wil sê toestande wat nie by die normale interpretasies kon inpas nie - oorheers het (Van Zyl 1992:19-20).

\section{DIE IDEOLOGIE VAN SATANISME}

Die ideologie van die kerk van Satan sluit ses aspekte en klemtone in, naamlik: hedonistiese (genotsugtige) bevrediging van aardse begeertes; die seremoniële gebruik van 
heksery om persoonlike mag te verkry en ander te manipuleer; die aanbidding van Satan as 'n simbool van dit wat religieus verbode en ketters is; die ikonoklastiese begeerte om jouself te bevry van konformistiese (ooreenstemmende) sosiale norme, verwagtings en institusionele beperkings; die chiliastiese geloof in die omverwerping van die Christendom en die koms van die nuwe wêreldorde; en die toekenning van charismatiese outoriteit en magiese lorag aan die religieuse leier of hoëpriester (Ivey 1993: 182).

\section{DIE KERK SE BESKOUING VAN SATANISME}

Die aard, voorkoms en betekenis van satanisme in Suid-Afrika is iets waaroor al hewig gedebatteer is. In die een kamp het ons die Christelike kerke wat 'n bo-natuurlike komplotteorie onderskryf. Hiervolgens is sataniste aktief betrokke in 'n globale demoniese plan om die geestelike fondasie van die Weste te vernietig, met die doel om 'n nuwe wêreldorde onder Satan se heerskappy tot stand te bring (Ivey 1993:180). In die teenoorstaande kamp is die wat redeneer dat die meeste stories van Sataniese aktiwiteite nie feitelik waar is nie, maar eerder 'n 'stadslegende' is, wat aangestook word deur die publieke histerie en verder deur die sensasionele massamedia dekcking (Ivey 1993:180). 'n Derde groep (waarmee ek my sou wou vereenselwig) huldig die standpunt dat die fenomeen van satanisme slegs deel uitmaak van 'n subkultuur wat onder hoofsaaklik jongmense posvat en as sodanig hanteer moet word (Ivey 1993:183).

\section{ONDERSKEIDING BINNE SATANISME}

Dit gebeur dat 'n wye reeks afwykende bedrywighede verkeerdelik as satanies geêtiketteer word as gevolg van 'n gebrek aan wetenskaplike data en die probleem met statistiese veralgemening omtrent sataniese aktiwiteite.

Navorsing wat deur Ivey (1993:183) gedoen is oor 'n tydperk van twee jaar, het die lig laat val op drie onderskeie groepe binne satanisme wat coreenstem met verskillende vlakke van kennis aangaande die kultus, ideologiese verbintenisse en organisatoriese betrokkenheid. Die eerste groep regverdig skaars die sataniese etiket. Die groep bestaan gewoonlik uit blanke adolessente wat ontvanklik is vir die kulturele paranoia rondom satanisme en teen gesagsfigure rebelleer deur hulle trou te betuig aan 'n afgewaterde sataniese ideologie. Konserwatiewe gesaghebbendes misinterpreteer die gedrag wat hulle vertoon (bv die deelname aan die Heavy Metal subkultuur, die dra van swart klere, die teken van sataniese beelde, die dra van sataniese tekens en simbole en die deelname aan okkultiese speletjies) verkeerdelik as satanies. Hulle naiewe verstaan van satanisme, die gebrek aan georganiseerde aktiwiteite en die feit dat hulle rebelleer teen alle gesagsstrukture en tradisionele norme in die soeke na hulle eie identiteit, on- 
derskei die groep van satanisme. Vanweè die sosiale sigbaarheid van die groep, is die groep grootliks verantwoordelik vir die publieke wanpersepsie dat die verskynsel van satanisme epidemiese afmetings in Suid-Afrika bereik het.

Die tweede groep bestaan uit jongmense (gewoonlik blanke adolessente) wat lede is van 'n georganiseerde sataniese kultus en wat al deelgeneem het aan formele rituele. Tog koester hulle ambivalente gevoeiens jeens satanisme, wat hulle totale verbintenis aan en identifisering met die sataniese ideologie verhoed. Hierdie groep voel dikwels ongemaklik met sekere seremoniële praktyke, hulle toon gebrek aan gedetaileerde begrip omtrent die betekenis van die rituele en hulle beklee ook die laagste rang in die hiërargie van die kultus. Hulle toon dikwels simptome van demoniese binding, selfs nadat hulle die kultus verlaat het. Hulle voer vrees vir geestelike en fisiese vergelding aan as primêre motief waarom hulle nie met satanisme breek nie. Hulle ambivalensie het tot gevolg dat hulle die kultus verlaat na 'n kort tydperk van betrokkenheid. Hierdie groep is baie kleiner as die eerste. Lede van hierdie groep, wat die groep verlaat het, vertoon dikwels verbandhoudende psigologiese versteurings. Baie het psigologiese probleme wat hulle kultus betrokkenheid voorafgaan en wat hulle gevolglik meer vatbaar maak vir Sataniese betrokkenheid.

Die derde groep bestaan uit die 'harde kern' wat goed ingelig is oor die betekenis van die sataniese rituele, entoesiasties daaraan deelneem en die rituele inisieer. Hierdie individue beklee statusposisies binne die hiërargie van die kultus. Oor die algemeen is die persone ouer as dié in die eerste en tweede groep. Hulle is vir 'n langer tydperk reeds betrokke en na bewering inisieer hulle self 'n reeks afwykende praktyke. Om toegang tot hierdie groep individue te verkry, is prakties onmoontlik vanweë die vlak van hulle ideologiese verbintenis en beweerde kriminele lewenswyse - absolute geheimhouding word gehandhaaf.

\section{VATBAARHEID?}

Die argument word gevoer dat die skynbare toename in sataniese aktiwiteite verband hou met die sosiaal-ekonomiese konteks van radikale kultuurveranderings, beroeringe en sosiale onstabiliteit (Ivey 1993:180). Adolessente wat vandag vervreemd, angstig en magteloos voel, word deur satanisme aangetrek as 'n middel om magiese krag en beheer oor hulle lok te verkry. Satanisme bevredig ook spesifieke sielkundige behoeftes wasrvoor daar nie voorsiening gemaak word deur ander vorme van religieuse aanbidding nie (Ivey 1993:180).

Volgens Ivey (1993:180) is die aantreklikheid van satanisme soortgelyk aan dié van enige ander fundamentele godsdiens in soverre dit die volgende bied: 
* Absolute ondubbeisinnige en cenvoudige antwoorde op die betekenis en sin van die lewe. Mense wat aan 'n gebrek aan selfvertroue lei, wat onseker is oor hulle eie eksistensie en 'n behoefte het aan 'n totalistiese geloofsstruktuur vind religieuse fundamentalisme baie aantreklik.

* Oombliklike aanvaarding deur die kultus en 'n gevoel van eiewaarde wat saam verkry word, voorsien verligting van vervreemding en eensaamheid. Mense wat hulleself as buitestanders beskou van die gemeenskap waarvan hulle nog altyd deel was, vind genoegdoening in 'n geredelike (onvoorwaardelike) aanvaarding.

* Die emosionaliteit en opwinding binne die religieuse kultusse bring behaaglikheid (euforie) te weeg en verskaf an die lede 'n gevoel van mag en lewenskrag (vitaliteit) wat enige neiging tot 'n gebrek aan eie waarde en depressie teenwerk.

Ons sou nou die vraag kon stel waarom sommige mense in die besonder deur satanisme aangetrek word. Een rede wat aangevoer kan word is dat satanisme aan sekere psigologiese behoeftes beantwoord wat nie deur ander religieuse kultusse beantwoord word nie. Ivey (1993:183-184) identifiseer die volgende behoeftes:

* Satanisme verskaf religieuse goedkeuring vir die bevrediging van begeertes wat normaalweg taboe is in ander godsdienste. Rituele seksuele bevrediging en die openlike uitdrukking van vyandigheid teenoor dit waarvan jy nie hou nie (dikwels deur ' $n$ vernietigende towerformule of bede) word deur satanisme aangemoedig.

* Satanisme legitimeer rebellie teen tradisionele ortodokse gesagsfigure en morele sisteme. Dit verskaf dus 'n weg om sonder vrees vir vergelding op te tree teenoor frustrerende sosiale beperkings en simbole van gesag.

* Sataniese betrokkenheid is dus dikwels die bewustelike of onbewustelike poging om wraak te neem teen dié wat die satanis blykbaar verkeerd of onregverdig behandel het, veral ouerfigure. Die verwerping van God die Vader en die aanbidding van Satan is die uiterste vorm van rebellie teen ouerlike outoriteit.

* Omdat satanisme destruktiewe optrede aanmoedig en regverdig, verlig dit die skuldgevoel wat dikwels ontstaan as gevolg van die uitdrukking van vyandigheid en die cortreding van innerlike waardes. Satanisme is nie gebaseer op die aanbidding van die bose nie, maar op die cortuiging dat wat die Christendom boos noem, eint- 
lik goed is. Satanisme bied dus al die voordele aan wat die godsdiens inhou, sonder die negatiewe spektrum van skuld wat 'n konstante verskyning van die Christelike godsdiens is.

* Die kwynende sosiale invloed van die Christendom en die toename in sosiale probleme laat die Christene se Christus swak voorkom en buite beheer van die sosiale chaos rondom ons. Dié wat God aanbid, lyk magteloos en onbeholpe om hulle eie lot te beheer. Dit laat satanisme na 'n meer lewensvatbare en kragtige alternatiewe ideologie lyk, wat die moontlikheid bied van meer selfbeheer en vervulling as die Christendom.

Louw (1992:251-253) bied die volgende konteksvelde wat moontlik as die teelaarde van satanisme beskou kan word:

* Die kinderjare, sosiale konteks en uitstaande gebeure wat die persoon gedurende sy of haar skoolloopbaan beinvloed het. Hierdie gebeure kon baie negatief gewees het en 'n traumatiese effek op 'n persoon gehad het.

* Kommunikasiepatrone tussen die ouers asook tussen die ouers en die kinders. Interaksiepatrone wat tot 'n negatiewe gesinsklimaat (vyandigheid, afstand en rebellie) gelei het, kan kinders moontlik daartoe gedryf het om 'warmte' en aanvaarding elders te soek.

* Moreeletiese kwessies wat die persoon se lewensbeskouing en standpunte raak.

* Mediese geskiedenis: Verskillende siektetoestande in die verlede kon 'n uitwerking op persoonlike gedrag gehad het.

* Seksuele ervarings: In die seksuele rypwordingsproses van 'n mens is daar heelwat faktore wat die proses van seksuele integrasie bepaal. Verkragting, kindermolestering, homoseksuele kontakte, buite-egtelike swangerskappe is almal traumatiese gebeure wat seksuele identiteit beinvloed.

* Belangrike gebeure wat die persoon se prestasievermoë beinvloed het. 'n Negatiewe selfervaring lei noodwendig tot 'n negatiewe selfbeeld. 
* Intense godsdienstige ervarings van bekering is dikwels dramaties en hang saam met uitstaande gebeure in hulle lewe. Emosionele druk en neersiagtigheid veroorsaak soms twyfel wat weer in spesifieke godsdienstige probleme na vore tree.

* Godsbeeld: Die bepaalde siening van God speel dikwels 'n beslissende rol in die hantering van godsdientige probleme. Wanneer God as 'n hardvogtige tiran beskou word, of as 'n straffende regter, gaan hierdie Godskonsep 'n belangrike rol speel in die persoon se geloofsinterpretasie van 'n spesifieke lewensituasie.

Op grond van bogenoemde kan die volgende profiel van 'n satanis geskets word:

Die pre-satanis is 'n tipiese rebelse, blanke, middelklas adolessent, vervreem van sy of haar familie en geisoleer van die eie portuurgroep. Die portuurgroep se aktiwiteite word met minagting geag en om te kompenseer vir 'n gevoel van magteloosheid, word gefantaseer oor weerwraak en die dood. Hy of sy smag na status, 'n wete dat hy of sy iewers behoort en na 'n gevoel van beheer oor die eie lewe. Wanneer die 'presatanis' aanvaar word binne 'n sataniese kultus bied dit 'n mate van sin en vervulling wat andersins afwesig is. Die neiging bestaan om toevlug te neem tot destruktiewe vorme van ontvlugting en sensasie soekende gedrag.

\section{8. 'N SIELKUNDIGE PERSPEKTIEF OP SATANISME}

Die vraagstuk na die verhouding tussen satanisme en die sielkunde het die afgelope jare 'n oplewing beleef en roep onmiddellik etlike verwante vrae op. Vrae soos byvoorbeeld: Hoe moet psigopatologiese toestande soos byvoorbeeld meervoudige persoonlikheidsversteuring en skisofrenie in die lig hiervan verstaan word? Manifesteer satanisme noodwendig as ' $n$ vorm van abnormale gedrag? Sluit die diagnosering van psigopatologie aan die hand van bepaalde diagnostiese kriteria noodwendig die moontlike voorkoms van satanisme uit? Hierdie vrae kan vermenigvuldig word. Wat egter dadelik opval, is die talle slaggate en moeilike vaarwaters warin 'n mens beland as hierdie vraagstuk vanuit 'n multidissiplinêre veld aangespreek word (Rossouw 1992:32). Vanwee die noodsaak vanuit die praktyk om koers te vind in sinvolle hanteringswyses word hier slegs gepoog om iets van die problematiek op enigsins gesistematiseerde wyse op die diskussietafel te plaas. Hier word dus nie voorgegee om 'n volledige oorsig of analise van die hele saak te bied nie (Rossouw 1992:32).

Binne die konteks van 'n demonologiese diskoers, kan die verskynsel van demoniese besetenheid en sataniese rituele betrokkenheid, verstaan word as die psigiese infil- 
trasie van kwaadwillige bonatuurlike entiteite. Die persoon wat egter hierdie verskynsel sielkundig wil verstaan en die demonologiese model verwerp, word gefrustreer deur die gebrek aan wetenskaplike materiaal oo: die onderwerp. Ivey (1992:186) skryf 'n artikel waarin hy 'n bydrae wil lewer deur die ontwikkeling van 'n objekverhouding psigo-analitiese model van onvrywillige demoniese besetenheid, sowel as vrywillige deelname in sataniese rituele. Hy begin met 'n ondersoek na die Freudiaanse siening van demoniese besetenheid, deur gebruik te maak van psigoanalise.

Freud publiseer slegs een werkstuk oor demoniese besetenheid. Hierdie werkstuk, getiteld $A$ seventeenth-century demonological neurosis (1923), is 'n psigologiese interpretasie van 'n historiese manuskrip wat ' $n 17 e$ eeuse kunstenaar se pakt met die duiwel en die simptomatiese gevolge daarvan detailleer. Ter inleiding van sy werkstuk stel Freud dat demone in die algemeen spruit uit die projeksie van onderdrukte impulse:

In our eyes, the demons are bad and reprehensible wishes, derivatives of instinctual impulses that have been repudiated and repressed. We merely eliminate the projection of these mental entities into the external world which the middle ages carried out; instead, we regard them as having arisen in the pasient's internal life, where they have their abode.

(Ivey 1992:186)

Uit Freud se werkstuk kan die volgende algemene gevolgtrekkings gemaak word omtrent sy verstaan van demoniese besetenheid. Eerstens beskou hy demoniese besetenheid as 'n vorm van neurose, wat gevolglik eerder 'n sielkundige as 'n bonatuurlike oorsprong het. Projeksie is dus die sentrale psigiese meganisme wat verantwoordelik is vir die persepsie dat demone tasbare eksterne figure is. Tweedens is alle gode geprojekteerde beelde van impulse en persepsies afkomstig van ervarings vanuit die vroeè kinderjare van 'n sterk vaderlike figuur in die persoonlike geskiedenis van die individu. Die pa is die vaderlike figuur waarop die duiwel gemodelleer is, vervorm deur die kind se destruktiewe en vreesagtige fantasieè. Beide God en die duiwel is simboliese projeksies v̀an die kind se teenstrydige ervaring van die enkel vader. Derdens is demoniese besetenheid ' $n$ neurotiese oplossing vir ' $n$ kind wat sy of haar vader verloor het, en wat die verlies nie suksesvol kan betreur nie. Vierdens veronderstel bevryding van demoniese besetenheid eksorsisme, waar die duiwel uitgedryf word deur 'n mag sterker as die duiwel self.

Die feit dat Freud sy analise op 'n obskure 17e eeuse dokument moes baseer, eerder as op gevallestudies van sy eie pasiënte, getuig daarvan dat sy spekulasie omtrent 
demoniese besetenheid nie ondersteun word deur ander empiriese data nie. As rede vir die gebrek aan addisionele getuienis, voer hy aan dat daar 'n historiese afname in die belang van die duiwel in Christelike mitologie is en gevolglik in die individu se psige. Die klassieke Freudiaanse metateorie is egter onbevredigend omdat alle psigologiese fenomene verklaar word in terme van instinktiewe impulse en die verdedigingsmeganismes wat hierteen opgerig word binne die konteks van die ouer-kind verhouding.

Ivey (1993:186) stel 'n alternatiewe objekverhouding model voor, gebaseer op die teoriee van Melanie Klein en Ronald Fairbairn. Op grond van 'n gevallestudie word voorgestel dat die internalisasie van 'n negatiewe ouerlike objek die ontwikkellende nukleus van demoniese besetenheid konstitueer. Die intrusiewe terugkeer van die geprojekteerde negatiewe objekverhouding gee aanleiding tot 'n ervaring van besetenheid. Dit wil egter voorkom dat daar, in die vrywillige deelname aan satanisme, 'n andersoortige dinamiek betreffende die individu se identifikasie met die negatiewe introjek aan die werk is. Die onbewuste motivering vir hierdie identifikasie spruit voort uit die kind se ervaring van kwesbaarheid en magteloosheid ten aansien van die ouerlike teistering. Die identifikasie met hierdie negatiewe objek, gesimboliseer deur Satan, gee die individu 'n gevoel van persoonlike mag en kontrole oor sy of haar lewe. Betrokkenheid in satanisme kompenseer dus vir die oorspronklike narcistiese skade aan die lewe van die kind.

Hierdie oplewing in die vraag na die verband tussen die sielkunde en satanisme kan hoofsaaklik toegeskryf word aan die bekendmaking van getuienis van beweerde oorlewendes van kultus praktyke, wie se getuienisse deur psigiaters en sielkundiges gemagtig is. Hierdie ooggetuies kan in twee groepe verdeel word, naamlik:

* volwassenes wat beweer dat hulle grootgeword het in kultusse wat hulle 'gebreinspoel' het deur middel van rituele marteling, en

* baie jong kinders, wat na bewering aan rituele marteling onderwerp is deur kultusnuwelinge terwyl hulle in dagsorg was.

Beide hierdie groepe het hulle herinneringe van hierdie angswekkende ondervindinge gedissosicer en dit cers onlangs in psigoterapie herontdek (Mulhern 1991:145). In die vroee tagtiger jare is intensiewe ondersoeke geloods na aanleiding van die bewerings wat gemaak is deur die beweerde slagoffers van rituele marteling. Tog is geen bewyse gevind wat hierdie beweringe kon staaf nie, wat dit hoogs onwaarskynlik gemaak het dat die beweringe waar was. Psigiaters en sielkundiges het die aantygings he- 
wig ontken dat die terapeutiese proses van openbaring, wat al gelei het tot buiten-gewone openbarings van volwasse oorlewendes wat aan geheueverlies gelei het en weerbarstige kinderslagoffers, die pasiēnte se beweringe beslissend gevorm het (Mulhern 1991:145).

Mulhern (1991:155) stel in sy artikel dat die meeste gemeenskappe uitdruklik erken dat die subjektiewe ervaring van 'n persoon wat deur 'n alternatiewe identiteit oorgeneem word, 'n baie werklike fenomeen is wat radikaal anders is as gedrag wat aan nabootsing toegeskryf kan word. Die erns hiervan word beklemtoon deur die feit dat alle gemeenskappe reëls vaslê waarby hulle hierdie fenomeen kan identifiseer en sosialiseer. Terapeute hou die volgende voor as bewys dat pasiënte slagoffers van rituele marteling is:

* geweld wanneer herinneringe aan kultus praktyke ontdek en herleef word;

* baie detail in die beskrywing van die rituele wanpraktyke;

* die manifestasie van liggaamlike 'herinneringe', soos byvoorbeeld, spontane bloeding, spier sametrekkings, die verskyning van merke op die vel ensovoorts;

* en hulle cortuiging dat pasiënte wat mekaar nog nooit ontmoet het nie, dieselfde dinge sê.

Daar word veronderstel dat slagoffers gewaarsku word dat hulle nie geglo sal word indien hulle iets van die kultus sou bekend maak nie. Deur dus die afskuwelike verhale wat ontvou, in twyfel te te trek, word die pasiënt verder geviktimiseer. Sexton (in Richardson, Best \& Bromley 1991:163) stel dit as volg:

I don't want any more survivors going into clinicians' offices feeling again that they are being re-abused by the mental health profession. If you do not believe that this could possibly happen, do not work with this issue, we don't want you a part of this because it is simply going to make the issue be more confounded and more difficult.

In 'n eie ondersoek deur Roussouw (1992:37) in 'n psigiatriese hospitaal blyk dit dat die volgende kriteria onder sommige psigiaters en sielkundiges as aanwysers vir besetting geld: 
* A-tipiese gedrag (gedrag/abnormale gedrag wat nie in die patroon van onderskeibare patologie val nie en nie organiese oorsake het nie).

* Kollaterale inligting uit die persoonlike en/of familiegeskiedenis (dat die persoon self by okkultiese bedrywighede betrokke was, of as die ouers daarby betokke was, as die bepaalde dade gepleeg is, byvoorbeeld die afswering van die bloed van Christus, vloek teen die Heilige Gees, die afswering van die Heilige Gees).

* Eienaardige outonome tekens (bv pupilvergroting as angs ervaar word waar daar normaalweg pupilverkleining voorkom, ooglede wat opspring).

* Manifestasies van 'n ander stem (dit kom ook voor by die meervoudige persoonlikheidsversteuring, maar hier is egter 'n drastiese verandering in stemkwaliteit asook die voorkoms van 'n ander taal).

* Eienaardige nie-verklaarbare fenomene (bv raak voorspellings deur die pasiënt omtrent dinge wat in 'n vertroulike gesprek oor hom of haar gesê is).

* Inhoud van spraak (daar is dikwels 'n spraakdruk en die inhoud is religieus gelaai en behep. Die vleeswording van Jesus Christus word ontken en aggressie kom dikwels na vore as daar van Christus as Verlosser gepraat word).

* Persoonlike aanvoeling deur die terapeut (dit hang nou saam met kollaterale inligting en a-tipiese gedrag; 'n skisofreen byvoorbeeld is afgestomp in sy of haar optrede en beleef delusies; hier kom dikwels ook delusionele optrede voor, maar die persoon is emosioneel skerp - daar is dikwels ' $n$ hatige houding te bespeur).

In die lig van voorafgaande analise van die aard en problematiek verbonde aan satanisme en die identifisering van besetting, dui Roussouw (1992:38-39) aan dat daar etlike gevare verbonde is aan die identifisering van moontlike besetting. 
Een van die gevare is dat besetting as leë-kol-diagnose bestempel kan word. Besetting word as laaste uitweg gediagnoseer as al die moontlike psigopatologie wat diagnoseerbaar is, afwesig is. Besetting moet dan die leë kol vul wat nie deur enige iets anders gevul kan word nie. Dan word besetting die laaste-uitweg-diagnose. Dit is ' $n$ groot gevaar aangesien die sielkunde en psigiatrie immers nog lank nie aanspraak maak op volledigheid of alleenreg op die veld van die geestessiektes nie. Die ander kant van die gevaar moet natuurlik ook in gedagte gehou word, naamlik dat die diagnosering van psigopatologie tog ook nie die moontlikheid van besetting kan uitsluit nie.

'n Tweede gevaar verbonde aan die diagnose van besetting is die krag van suggestie wat met die diagnose oorgedra word. Die gevolg kan wees dat die persoon begin optree in die lig van die diagnose juis as gevolg van die kragtige invloed van die suggestie van die diagnose. Voorts kan voortdurende diagnoses van besetting juis die voorkoms hiervan verhoog as gevolg van dieselfde suggestie.

Roussouw (1992:39) bied enkele riglyne vir die diagnosering en hantering van moontlike besetting wat vir pastors in die bediening ook van groot waarde kan wees:

* Die eerste riglyn is dat daar altyd 'n duidelike beeld voor oê gehou moet word oor die riglyne wat die Woord leer aangaande die mens, sy [of haar] verlossing.

* In die lig van al die moontlike gevare rondom diagnosering moet groot sorg gedra word om nie die toestand van persone te vererger nie. Die gevaar is nie denkbeeldig nie dat die omvang van die problematiek van die betrokke persoon telkens meer as net moontlike besetting is.

* Die derde riglyn is dat daar sover as moontlik altyd van 'n multiprofessionele span in die diagnosering van besetting gebruik gemaak sal moet word. Die noodsaak van omvattende evaluering van 'n persoon is van die grootste belang om te kom tot verantwoordelike en omvattende diagnosering met die oog op die gesondheid van die mens as geheel. 
* Die vierde riglyn is dat diagnosering van moontlike besetting altyd tentatief, sonder alarmisme en met die uiterste voorsorg en sensitiwiteit gedoen moet word. In die lig hiervan is sodanige diagnosering altyd ' $n$ laaste en uiterste beslissing.

* Laastens moet altyd onthou word dat besetting nie die enigste manifestasie van die bose is nie. Daar is baie subtiele vorms van demoniese invloede, en die mag van die bose moet nie cor- of onderskat word nie. In hierdie verband is dit belangrik om te waak teen 'n meganistiese benadering as sou die persoon sonder sy samewerking deur 'n meganistiese daad bevry word.

Bodemer (1987:138) lê groot nadruk daarop dat daar 'n in diepte ondersoek gedoen moet word na enige persoon (wat beweer dat hy of sy deur bose geeste beset word) se kulturele en religieuse agtergrond. Elke poging sal aangewend moet word om alle moontlikhede van organiese en psigiatriese siektes uit te skakel. Die verskynsel van satanisme is 'n werklikheid en eis gevolglik van elke Christen wat in die veld van die geestesgesondheid werksaam is 'n verantwoordelike omgaan daarmee. Hierdie verantwoordelikheid moet aanvaar word met groot afhanklikheid van die leiding van die Gees van Waarheid vanuit die riglyne van die Woord (Rossouw 1992:40).

\section{PASTORALE hULPVERLENING AAN DIEGENE VASGEVANG BINNE DE KLOUE VAN SATANISME}

Insoverre satanisme 'n psigologiese en sosiale realiteit is, moet dit emstig geneem word. Tog is objektiewe en gebalanseerde navorsing noodsaaklik om die religieuse paranoia en sensasionalistiese oormaat teè te werk (Ivey 1993:185). Dit is nodig dat die korrekte visie op die duiwel binne die pastorale situasie geopen moet word. Ten spyte van ons modeme leefwyse is bygeloof steeds net 'n haarbreedte ver weg. Van Zyl (1992:21) stel voor dat 'n onderdeel van die terapie moet wees: 'kyk, die keiser het dan nie eens klere aan nie!' Hiermee bedoel hy dat dit bevrydend is as iemand die moed aan die dag lê om die duiwelse betowering te verbreek en die Duiwel te ontmasker. Die Duiwel moet in die oē van die Christen die regte proporsie aanneem. Die Engelse uitdrukking stel dit so: 'he must be cut to size.'

Bevryding van 'n wêreldbeeld waar die Duiwel as 'n soort teen-God voorgehou word, moet plaasvind. 'n Bepaalde stuk ontmitologisering moet in die gemoed van die gelowige plaasvind. In die terapie mag die bygeloof van die mens nie verder gevoed 
word deur stilswyend erkenning te gee aan allerlei opvattings omtrent die Duiwel nie. Van Zyl (1992:21) noem dit rasionele geloofsterapie: mense moet met 'n stewige dosis Skrifkennis en -interpretasie 'n nuwe kosmologiese raamwerk gebied word waarbinne Satan in die regte perspektief gesien word.

Met ontmitologisering word nie bedoel om Rudolf Bultmann se hermeneutiese program uit te voer nie. Die bestaan van die bose word nie sonder meer ontken nie om byvoorbeeld aan mense te sê dat hulle dinge oor die duiwel verbeel nie. Niemand kan met te veel stelligheid oor die misterie van die lewe praat nie, veral nie as dit gaan oor die transendente nie. Die kosmos is te vol geheime. Tog, wanneer gegewens oor Satan en die Nuwe Testament geïnterpreteer word, kan die kennis waaroor beskik word aangaande die moderne kosmologie, nie opsygeskuif word nie. Daar kan beslis nie teruggekeer word na die wêreldbeeld van die antieke mens (met alles wat dit inhou vir die interpretasie van eietydse abnormale verskynsels) nie. Die vooruitgang van die wêreld sedertdien (met al die kennis en insig wat dit meegebring het) moet tog ook, as deel van God se voorsienige leiding en voortgaande leiding oor die skepping, gesien word (Van Zyl 1992:21).

Tog moet daar in dieselfde asem gesê word dat die pastor met begrip en deernis na sulke persone sal moet luister, aangesien hulle die wêreld van demone as 'n absolute werklikheid beleef. Ten einde sukses in die pastorale gesprek te bevorder, is dit van belang dat die pastor in ' $n$ 'taal' sal praat wat die lidmaat ontvanklik sal stem en wat sal ooreenstem met sy of haar verwysingsraamwerk. Ten spyte van die feit dat mense in 'n moderne wêreld leef, is die lidmaat steeds vasgevang in 'n mitiese verwysingsraamwerk - dit vra van die pastor 'n sensitiwiteit hiervoor. Die pastor sal 'n tree in die lidmaat se verwysingsraamwerk moet gee alvorens en indien die pastor die lidmaat oorhelp na 'n nuwe verwysingsraamwerk.

\section{SLOT}

Soos in die hipotese van hierdie ondersoek gestel, het dit uit die navorsing geblyk dat die persepsie van satanisme verband hou met die werklikheidsverstaan van die mens. Die ervaring van die realiteit van besetenheid kan in sommige gevalle ook in verband gebring word met psigologiese projeksies. Om lidmate wat demoniese besetenheid ervaar, pastoraal te. begelei, sal dus 'n genuanseerde pastorale strategie vereis. 'n Multidissiplinère benadering sal gevolg moet word om die 'besetenheid' vanuit verskillende gesigspunte te diagnoseer. Daar kan fisiese, psigiese en religieuse faktore wees wat die besetene se optrede verklaar of belig. Die pastor sal in die multi-dissiplinêre span hoofsaaklik verantwoordelik wees vir die religieuse dimensie. Om hierdie religieuse aspek effektief te hanteer sal die pastor erns moet maak met die werklikheidsverstaan 
van die pastorant. Indien die pastorant in 'n mitologiese werklikheidsverstaan vasgevang is, sal dit futiel wees om die pastorant se werklikheidsverstaan te probeer ontmitologiseer.

Die 'ervaring' van besetenheid, al sou dit in 'n moderne werklikheidsverstaan as religieuse of psigologiese projeksies verklaar kon word, word deur die pastorant as 'n realiteit beleef. Die oordra van die vryspraak, oorwinnig en almag van Jesus Christus, sal dus binne die mitologiese verwysingsraamwerk van die pastorant hermeneuties ingetolk moet word. 'n Getemperde weergawe van eksorsisme, soos in Bybeltekste weerspieël word, sal dus 'n meer geslaagde strategie wees. Die proklamering van die vryspraak van Christus en sy oorwinning oor die bose, sal in die pastorale gesprek of in die gebed die vorm van die bestraffing van die bose in die Naam van Jesus Christus impliseer. Christelike simbole soos in die studie aangetoon, kan hier ook 'n groot rol speel. Indien die pastorant 'n moderne ge-ontmitologiseerde werklikheidsbeskouing het, sal die sielkundige terapie waarskynlik daarin slaag om sy of haar besetenheid as psigologiese projeksie te laat verstaan. In so 'n geval sal die 'eksorsisme' ge-ontmitologiseer moet word.

Mense kan dus van die mitiese wêreld wees en tog in die moderne wêreld wees, maar nie van die moderne wêreld bewus wees nie. Die omgekeerde hiervan is dikwels vir die pastor ook waar. Die verdraagsaamheid van die pastor om die werklikheid van die pastorant se mitiese wêreld te betree is dikwels deurslaggewend. Begeleiding is nie altyd begeleiding van een plek na 'n ander nie - dus nie noodwendig uit 'n mitiese wêreld in 'n modeme wêreld in nie. Dit kan wel begeleidend binne die omgewing van die mitiese wêreld wees. Die taak van die pastor is dan nie om die wêreld van die pastorant te verander nie, maar wel die inhoud van die wêreld. Die slaggat waarin die pastor maklik kan trap, is om die mitiese wêreld te verwerp in plaas van die inhoud daarvan. Selfs wanneer die pastorant in die moderne wêreld aankom, 'verdwyn' die mitiese wêreld nie. Die wêreld bly steeds daar, gelyktydig met en naas die moderne wêreld. Die botsing tussen leefwêrelde bestaan dus. Dis net nie so opvallend as die 'godsdienstige' inhoud aanvaarbaar is nie.

'n Geloofstrategie sal dus nie probeer om die bose te oorskat nie. Daarvoor is Christus se oorwinningswerk aan die knuis en die opstanding te oormagtig. Dit sal ook nie probeer om die bose te onderskat nie. Daarvoor is die sonde te werklik. 'n Geloofstrategie is gesetel in die erkenning van skuld en die belydenis van sonde op grond van die heilsfeit dat die vryspraak 'n Goddelike oorsprong het. Die bose kan weerstaan word deur ' $n$ identiteit wat deur God self geborg word en wat deur gebed in werking gestel word (Louw 1993:93). 
Literatuurverwysings

Bodemer, W 1987. Satanism, witchcraft and the occult: A psychiatrist's view, in de Villiers P G R (ed), Like a roaring lion, 132-138. Pretoria: CB Powell Bible Centre.

Dreyer, T F J 1995. Pastorale modelle. Kernaantekeninge vir PRT 600. Ongepubliseerde studiehandleiding, Departement Praktiese Teologie (Afd A), Universiteit van Pretoria.

1990. Poimeniek I - Pastorale gesprekvoering. Kernaantekeninge vir PRT 500. Ongepubliseerde studiehandleiding, Departement Praktiese Teologie (Afd A), Universiteit van Pretoria.

1981. Poimeniek - 'n Pastorale orientasie. Pretoria: HAUM.

1992. Homiletiek: Van die teks na die preek. Kernaantekeninge vir PRT 500. Ongepubliseerde studiehandleiding, Departement Praktiese Teologie (Afd A), Universiteit van Pretoria.

Estadt, B K 1983. Pastoral counceling. New Jersey: Prentice Hall.

Ivey, I 1993. Psychodynamic aspects of demonic possession and satanic worship. Suid-Afrikaanse Tydskrif vir Siellaunde 23/4, 186-194.

- 1993. The psycology of satanist worship. Suid-Afrikaanse Tydskrif vir Sielkunde 23/4, 180-185.

Janson, M 1993. Is Satan vandag regtig los, in Joubert S \& van der Watt, J (reds), Satan ontbloot, 53-68. Vereeniging: Christelike Uitgewersmaatskappy.

Jonker, K 1993. Satanisme - 'n realiteit. Pretoria: Sigma-Pers.

Louw, D J 1993. Diagnostiese kriteria vir die evaluering van satanisme in die pastorale bediening, in Müller C (red), Praktiese Teologie in Suid-Afrika 8/2, 83-93.

1993. Pastoraat as ontmoeting: Ontwerp vir basisteorie, antropologie, metode en terapie. Pretoria: Die RGN-Uitgewery.

May, R 1980. The art of counceling. Nashville: Abingdon.

Mulhern, S 1991. Satanism and psycotherapy: A rumor in search of an inquisition, in

Richardson, J T, Best, J \& Bromley, D G (eds), The satanism scare, 145-172. New York: Aldine de Gruyter.

Nederduitsch Hervormde Kerk van Afrika 1987. Diensboek. Pretoria: Kital.

Pelser, G M M 1989. Rudolf Bultmann se ontmitologisering van die Nuwe-Testamentiese eskatologie. HTS 45, 815-842.

1987. Die ontmitologiseringsprogram van Rudolf Bultmann. HTS 43, 162191. 
Roussouw, P J 1992. Besete of siek? 'n Pastoraal-sielkundige perspektief op satanis$m e$, in Smit 1992:32-40.

Russell, J B 1977. The devil: Perceptions of evil from antiquity to primitive Christianity. Ithaca: Cornell University Press.

Smit, J H (red) 1992. Die evangeliebediening aan demonies (okkult) gekweldes. Bloemfontein: Pro Christo-Publikasies.

Thornton, E E 1992. Fragmentation anxiety and the balm of empathy: A pastoral care perspective on satanism. Review and Expositor 89, 515-526.

Van Aarde, A G 1987. Demonoly in New Testament times, in de Villiers P G R (ed), Like a roaring lion, 141-145. Pretoria: CB Powell Bible Centre.

Van der Watt, J 1993. Is Satan vandag regtig los, in Joubert $S$ \& van der Watt, J (reds), Satan ontbloot, 31, 35. Vereeniging: Christelike Uitgewersmaatskappy.

Van Zyl, H C 1992. Die Duiwel ontmasker: 'n Nuwe Testamentiese perspektief, in Smit 1992:9-22. 